\title{
Detection of Pathogenic Waterborne Parasites in Treated Wastewater of Rada'a City -Yemen
}

\author{
Faisal Mohammed Al-Nihmi ${ }^{1}$, Akram Ahmed Salih ${ }^{2}$, Jalal Qazzan ${ }^{3}$, Bakeel Radman ${ }^{1}$, Warda \\ Al-Woree ${ }^{1}$, Shefaa Belal ${ }^{1}$, Jamila Al-Motee ${ }^{1}$, Ahlam AL-Athal ${ }^{1}$, Ahlam Al-Harthee ${ }^{1}$, Hanan Al- \\ Samawee $^{1}$, Balkees Al-Samawee ${ }^{1}$, Horriah Atiah ${ }^{1}$ \\ ${ }^{1}$ Department of Biology, Faculty of Education \& Sciences, AL-Baydha University, Yemen
${ }^{2}$ Department of Laboratories, Faculty of Medical Sciences, AL-Hikma University, Thamar-Yemen.
${ }^{3}$ Department of Pharmacy, Faculty of Medical Sciences, AL-Hikma University, Thamar-Yemen.
}

\begin{tabular}{|c|c|}
\hline Articl & Abstract \\
\hline ory: & Purpose: The aim of this study is to detect the presence of waterborne \\
\hline 20 & $p$ \\
\hline & \\
\hline$A$ & $\begin{array}{l}\text { were concentrated using formol ether and zinc sulphate techniques and then } \\
\text { microscopically analyzed to identify protozoa and helminth eggs. Fifteen }\end{array}$ \\
\hline Key & $\begin{array}{l}\text { treated sewage samples were randomly collected from different positions of } \\
\text { wastewater treatment plant in three different months of } 2019 \text { (Mav, June and }\end{array}$ \\
\hline $\begin{array}{l}\text { ter, } \\
\text { ne } P\end{array}$ & $\begin{array}{l}\text { wastewater treatment plant in three different months of } 2019 \text { (May, June and } \\
\text { August) with three replications. Each sample was collected in one-litre }\end{array}$ \\
\hline t Plant, & $\begin{array}{l}\text { recorded as original sample. Parasite analysis was done using } \\
\text { ter worm egg counting slides with chamber size of } 0.3 \mathrm{~mm} \text {. }\end{array}$ \\
\hline $\begin{array}{l}\text { Transmission, } \\
\text { Rada'a }\end{array}$ & $\begin{array}{l}\text { Results: In this study, Giardia lamblia was found in a high percentage in } \\
\text { comparison to other parasites, followed by Entamoeba histolytica, }\end{array}$ \\
\hline & $\begin{array}{l}\text { Entamoeba coli. The majority of parasite eggs in the treated wastewater } \\
\text { samples were related to Hookworm and Ascaris lumbricoide followed by }\end{array}$ \\
\hline & $\begin{array}{l}\text { inat and Enterobius vermicularis. Furthermore, Cryptosprodium } \\
\text { Fasciola hepatica eggs were rarely detected. }\end{array}$ \\
\hline $\begin{array}{l}\text { Corresponding Author: } \\
\text { Faisal Mohammed AL-Nihmi } \\
\text { Email: }\end{array}$ & $\begin{array}{l}\text { Conclusion: The observed pattern of contamination demonstrated that the } \\
\text { quantity of parasites in sewage after treatment exceeded the permitted levels } \\
\text { and it is necessary to modify the treatment process of wastewater to prevent } \\
\text { the possible spread of parasitic contamination. }\end{array}$ \\
\hline
\end{tabular}

\section{Introduction}

Sewage discharges are the most risk factors for the introduction of parasites (enteropathogens) into lakes, streams and ground water that serves as an important vehicle of pathogen transmission in unhygienic conditions. Surface drinking water or water storage containers are readily contaminated by faecal matter, resulting in a high background level of infectious parasites in developing countries (5-12 episodes per child/year) (Hespanhol, 1997; Guerrant et al.,1990). Basically, sewage contains chemical contaminants (organic and inorganic compounds), microorganisms and useful nutrients which improve soil fertility (Zurit $\&$ White, 2014). However, the use of untreated sewage causes risks of transmission of diseases to the community (Okoh et al., 2007). 
Microorganisms in sewage are a mixture of pathogenic and non-pathogenic. These organisms can be found in sewage effluents, livestock (cattle, sheep, etc.), farming activities, domestic animals and wildlife. Most of the pathogenic microorganisms available in sewage can be characterized as protozoa, helminths, bacteria or viruses. Several protozoan infectious agents have been recognized as waterborne pathogens such as Giardia lamblia, Cryptosporidium parvum, Entamoeba histolytica and Entamoeba coli (Steiner, Thielman, \& Guerrant, 1997). Helminth eggs are also other common parasitic elements that can be documented in sewage water. The most common types of helminths detected in sewage are Roundworm, Whipworm, Threatworms and Hookworms (Miegeville et al., 2003). The variation of the different types and concentrations of parasites in untreated wastewater through the year seasons depends on human activity, intensity of domestic animals, the seasonality of infections and/or concentration of non-domestic wastewater (WHO et al., 2006).

Direct discharge of crude, untreated sewage into recreational areas will cause a serious risk to public health. Control of sewage pollution by holding sewage in storage for varying periods of time is practised by most of the countries in the world to reduce environment pollution (Miranzadeh \& Mahmodi, 2002). The techniques used for sewage treatment vary widely, of these, lagooning, primary plus secondary treatment, tertiary treatment and disinfection. Using all these techniques will effect a significant reduction in index organism and pathogen contamination of treated wastewater (Patricia et al., 2008). Parasitic elements such as worm eggs and protozoa cysts are often detected in sewage because these elements have high resistance to chlorine or ozone commonly used in wastewater treatment systems (Hatam et al., 2015; Alouini, 1993).

Treated wastewater is a source for irrigation and fertilization in agriculture in many countries of the world. However, the use of untreated or partially treated wastewater causes severe risks and possible transmission of diseases to farmers, plants irrigated by this water and maybe into surface sources of drinking water. Protozoa and some other types of helminths have been reported as the most resistant parasites to wastewater treatment methods that facilitate their survival and prevalence in the environment. Therefore, sewage treatment plants have the potential to be a source of parasitic contamination to our environment, drinking water and agriculture fields if the treatment processes used do not sufficiently treat the effluents before being discharged (Lim, Hafiz, \& Nissapatorn, 2007). Given this background, this study is an attempt to investigate the presence of parasites in the treated sewage from Rada's wastewater treatment plant.

\section{Methodology and Procedures}

In this study, fifteen treated sewage samples were randomly collected from different positions of wastewater treatment plant in three different months of 2019 (May, June and August) with three replications. Each sample was collected in one-litre volume and recorded as original sample. 


\section{Samples Preparation}

The collected samples of the treated sewage water were subjected to filtration immediately after collection using nylon tea strainer to remove debris or sand pollution. Filtered samples were placed at rest for 2 hours to allow parasite precipitation, and then, $90 \%$ of the supernatant was removed using a vacuum pump. Sediments were transferred into centrifuge tubes and centrifuged at $1000 \mathrm{~g}$ for 15 minutes. The supernatant was discarded and each sediment was suspended in $10 \mathrm{ml}$ of buffer $(\mathrm{pH}=4.5)$.

\section{Parasites Concentration}

The formol-ether concentration technique was used to concentrate a wide range of parasites from water. Prepared samples were transferred into Falcon tubes and centrifuged at $1000 \mathrm{~g}$ for 1 minute. Supernatant was discarded and sediment was suspended in $6 \mathrm{ml}$ of $10 \%$ formol water. After mixing, $4 \mathrm{ml}$ of diethyl ether were added into tube and the whole contents in the tube were mixed by vortexing until a uniform mixture was achieved. The mixture was centrifuged at $1000 \mathrm{~g}$ for 1 minute. The supernatant (ether, water debris and formol water) was removed using Pasteur pipette and the pellet is either suspended in saline if sample used for wet preparation, smears preparation and protozoa numeration (Cheesbrough, 2004), or suspended in zinc sulphate solution 33\% (1.18 density) and recorded as final volume if the sample is used for helminth eggs quantification (Eaton et al., 2005).

\section{Wet and Smears Preparation}

For detecting protozoa trophozoites, we used the direct examination method. Small amount of sample suspension was transferred into a slide and covered with glass round cover. For smears preparation, about $0.1 \mathrm{ml}$ of suspension was transferred by Pasteur pipette into one end of the sterilized glass slide and immediately spread into a thin film using a smooth-edged slide spreader. Smears were left to dry for few minutes and then fixed in absolute methanol for ten seconds. After drying of alcohol, smears were stained using different types of vital stains such as: Methylene blue, Carbol fuchsin, Red methyl, Indian ink and Giemsa. Ziehl-Neelsen method was used for Cryptosporidium diagnostic. All stains brought as working solution from commercial sources and each stain was used as described by Cheesbrough (2005). The prepared smears and wet preparations were examined under light microscope using 40X objective to observe protozoa and 10X objective for the observation of helminth eggs.

\section{Parasites Numeration}

Parasite analysis was done using the McMaster worm egg counting slides with chamber size of $0.3 \mathrm{~mm}$ as described in the standard methods by Eaton, 2005. The Zinc sulphatesediment mixture was quickly transferred to McMaster slide chambers using a Pasteur pipette. The slides were placed on a flat surface for 5 minutes to allow the eggs to float on the surface. McMaster slides were placed under microscope and observed by 40X objective. All helminth 
eggs found in the grid chamber were counted carefully. Finally, the number of eggs per litre of sample was calculated using the following equation:

\section{$\mathrm{N}=\mathrm{AX} / \mathrm{PV} \times 1$}

$\mathrm{N}$ : Number of eggs per litre of sample;

A: The number of parasite eggs counted per slide (average of two or three slides);

$\mathrm{X}$ : Volume of the final sample;

P: Volume of McMaster slide $(0.3 \mathrm{~mL})$;

$\mathrm{V}$ : Volume of the original sample (L).

Protozoa were enumerated after the concentration of the sample size 1 litre to $1 \mathrm{~mL}$ by using the chamber Nebular slide, according to the following equation:

(Number of organisms $/ \mathrm{mL}=$ number of organisms counted/number of $\mathrm{mm}^{5} \mathrm{~m}^{3} \backslash \mu \mathrm{L}$ ).

However, the methods utilized to detect or to count the protozoan parasites do not differentiate between viable and nonviable organisms (Ortolani, 2000).

\section{Results and Discussion}

In this study, we have detected different types of parasites in treated wastewater mostly related to protozoa and helminths. Microscopic examination of wet and smear preparations showed the presence of different stages (cysts, trophozoits or oocysts ) for Entamoeba histolytica, Entamoeba coli. (Figure- 1a-f) and Giardia lamblia (Figure-2). Cryptosprodium oocysts were detected in Ziel Neelsen preparation (Figure-1g)

The results showed that using different vital stains was useful for identifying protozoa stages. For example, Methylene blue facilitates differentiating between cyst stages of Entamoeba histolytica and Entamoeba coli . Moreover, flagella in Giardia trophozoites clearly appear in carbol fuchsin preparation in comparison with saline wet preparation, whereas cyst stage of this parasite was detected in Methylene blue Indian ink and saline preparations.

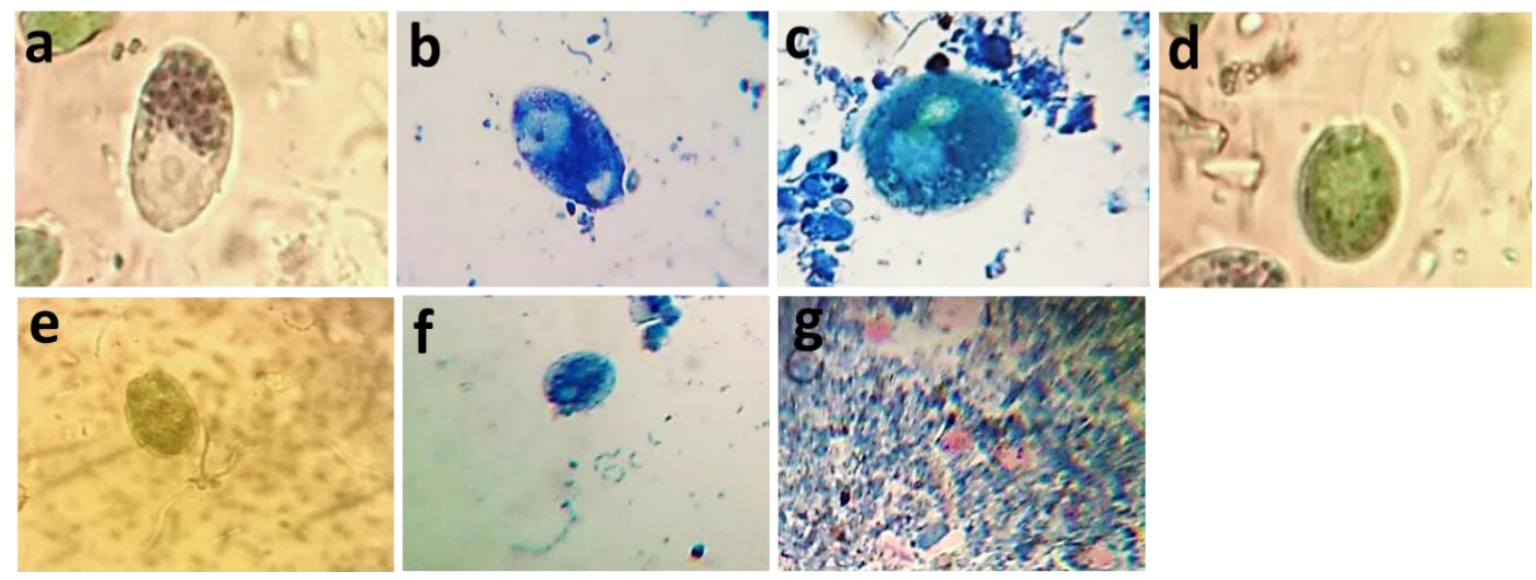

Figure 1: (a) Entamoeba histolytica trophozoite (saline), (b) Entamoeba histolytica trophozoite (Methylene blue), (c) Entamoeba histolytica cyst (Methylene blue), (d) Entamoeba coli trophozoite (saline),(e)Entamoeba coli cysts (saline), (f)Entamoeba coli cysts (Methylene blue), (g) Cryptosprodium oocyst (Ziel Neelsen).

ISSN: 2709-0159(Print)

Copyright (C) 2020, Journal of Scientific Research in Medical and Biological Sciences (JSRMBS), Under the license CC BY- 4.0 

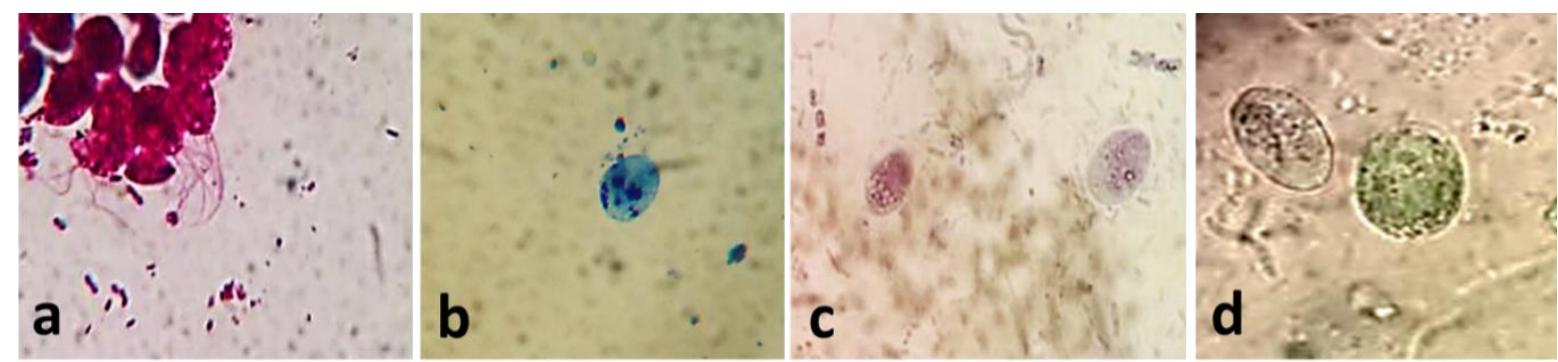

Figure 2: (a) Giardia trophozoite (Carbol fuchsin), (b) Giardia cysts(Methylene blue), (c) Giardia cysts(Indian ink), (d) Giardia cysts and Entamoeba coli trophozoite (saline).

In addition to protozoa, five types of helminth eggs including Hookworms, Ascaris lumbricoide, Taenia saginat, Fasciola hepatica and Enterobius vermicularis were clearly detected in iodine and saline preparations as shown in figure no.3.
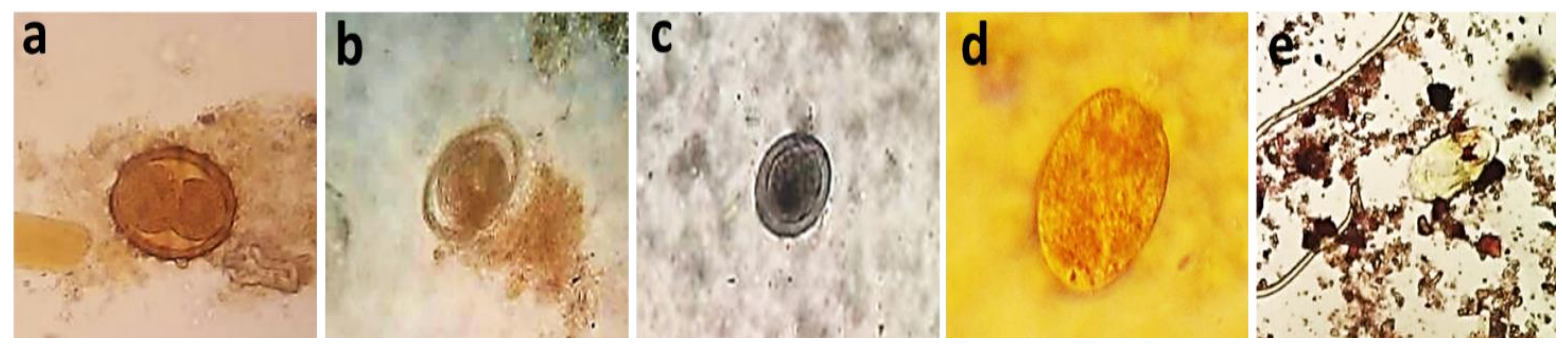

Figure3: (a) Ascaris lumbricoide fertilized egg (b) Hookworm egg, (c) Taenia saginat egg, (d) Fasciola hepatica egg, (e) Enterobius vermicularis egg.

The mean abundance and dominance of parasites were determined for all samples collected in May, June and August, individually. Generally, Giardia lamblia was found in most abundance followed by Entamoeba histolytica, Entamoeba coli, Hookwarms eggs and Ascaris lumbricoide eggs respectively. Fasciola hepatica eggs and Cryptosprodium oocysts were observed with low frequency, solely, in August samples, whereas, Taenia saginat eggs were detected in June samples with moderate number. The samples collected in May included a significant number of Enterobius vermicularis eggs which were not observed in other months (Table-1). 
Table1: Mean Number and Dominance of Parasites in Different Sampling Points.

\begin{tabular}{|l|c|c|c|c|c|c|}
\hline \multicolumn{1}{|c|}{$\begin{array}{c}\text { Name of } \\
\text { Parasite }\end{array}$} & $\begin{array}{c}\text { No. Of } \\
\text { Parasite/lit } \\
\text { in May }\end{array}$ & $\begin{array}{c}\text { Dominanc } \\
\text { e in May }\end{array}$ & $\begin{array}{c}\text { No. Of } \\
\text { Parasite/lit } \\
\text { in June }\end{array}$ & $\begin{array}{c}\text { Dominance } \\
\text { in June }\end{array}$ & $\begin{array}{c}\text { No. Of } \\
\text { Parasite/lit } \\
\text { in August }\end{array}$ & $\begin{array}{c}\text { Dominance } \\
\text { in August }\end{array}$ \\
\hline Hookworm(eggs) & 50 & $8.46 \%$ & 37 & $5.27 \%$ & 55 & $7.60 \%$ \\
\hline $\begin{array}{l}\text { Ascaris } \\
\text { lumbricode }\end{array}$ & 57 & $9.64 \%$ & 40 & $5.69 \%$ & 30 & $4.14 \%$ \\
\hline $\begin{array}{l}\text { Taenia saginat } \\
\text { (eggs) }\end{array}$ & - & - & 35 & $4.98 \%$ & - & - \\
\hline Fasciola hepatica & - & - & - & - & 12 & $1.65 \%$ \\
\hline $\begin{array}{l}\text { Enterobius } \\
\text { vermicularis } \\
\text { (eggs) }\end{array}$ & 40 & 6.76 & - & - & - & - \\
\hline $\begin{array}{l}\text { Giardia } \\
\text { lamblia(cysts and } \\
\text { trophozoits) }\end{array}$ & 210 & $53.53 \%$ & 290 & $41.31 \%$ & 315 & $43.56 \%$ \\
\hline $\begin{array}{l}\text { Entamoeba } \\
\text { histolytica(cysts } \\
\text { and trophozoits) }\end{array}$ & 140 & $23.68 \%$ & 180 & $25.64 \%$ & 125 & $17.28 \%$ \\
\hline $\begin{array}{l}\text { Entamoeba } \\
\text { coli(cysts and } \\
\text { trophozoits) }\end{array}$ & 94 & $15.9 \%$ & 120 & $17.09 \%$ & 106 & $14.66 \%$ \\
\hline $\begin{array}{l}\text { Cryptosprodium } \\
\text { (Oocysts) }\end{array}$ & - & - & - & - & 80 & $11.06 \%$ \\
\hline
\end{tabular}

Source: Authors

In comparison to parasite abundance (percentage \%) during the targeted time points, the abundance of detected protozoa decreased gradually from May to August except Cryptosprodium oocycts that was absent in May and June in the tested samples. For helminths, the abundance of Hookworms eggs and Ascaris lumbricoide eggs was higher in June in comparison to their presence in the other months (Figures-4A, 4B and 4C).

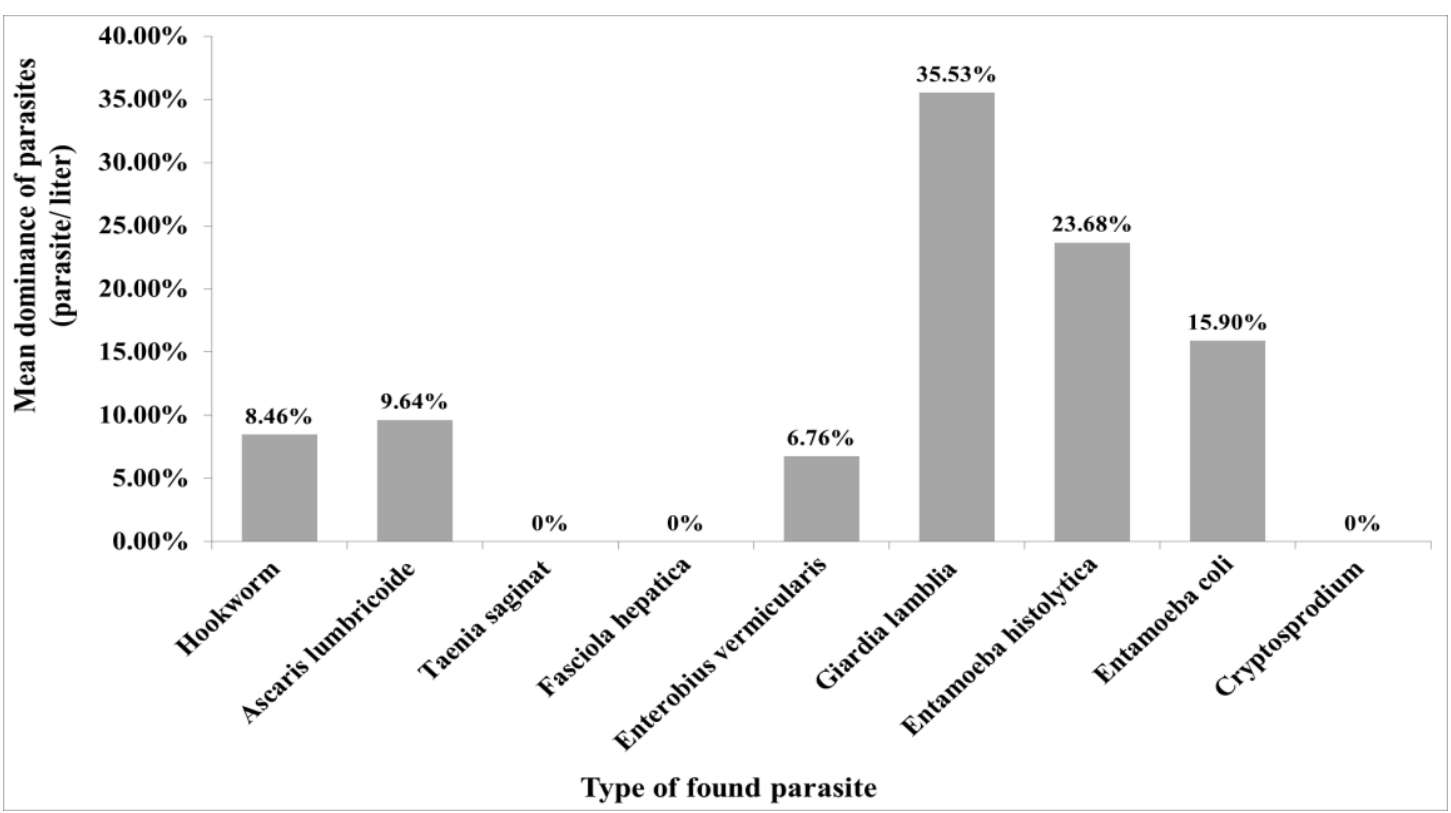

Figure 4a: Mean dominance of parasites in May sampling point.

ISSN: 2709-0159(Print)

Copyright (c) 2020, Journal of Scientific Research in Medical and Biological Sciences (JSRMBS), Under the license CC BY- 4.0 


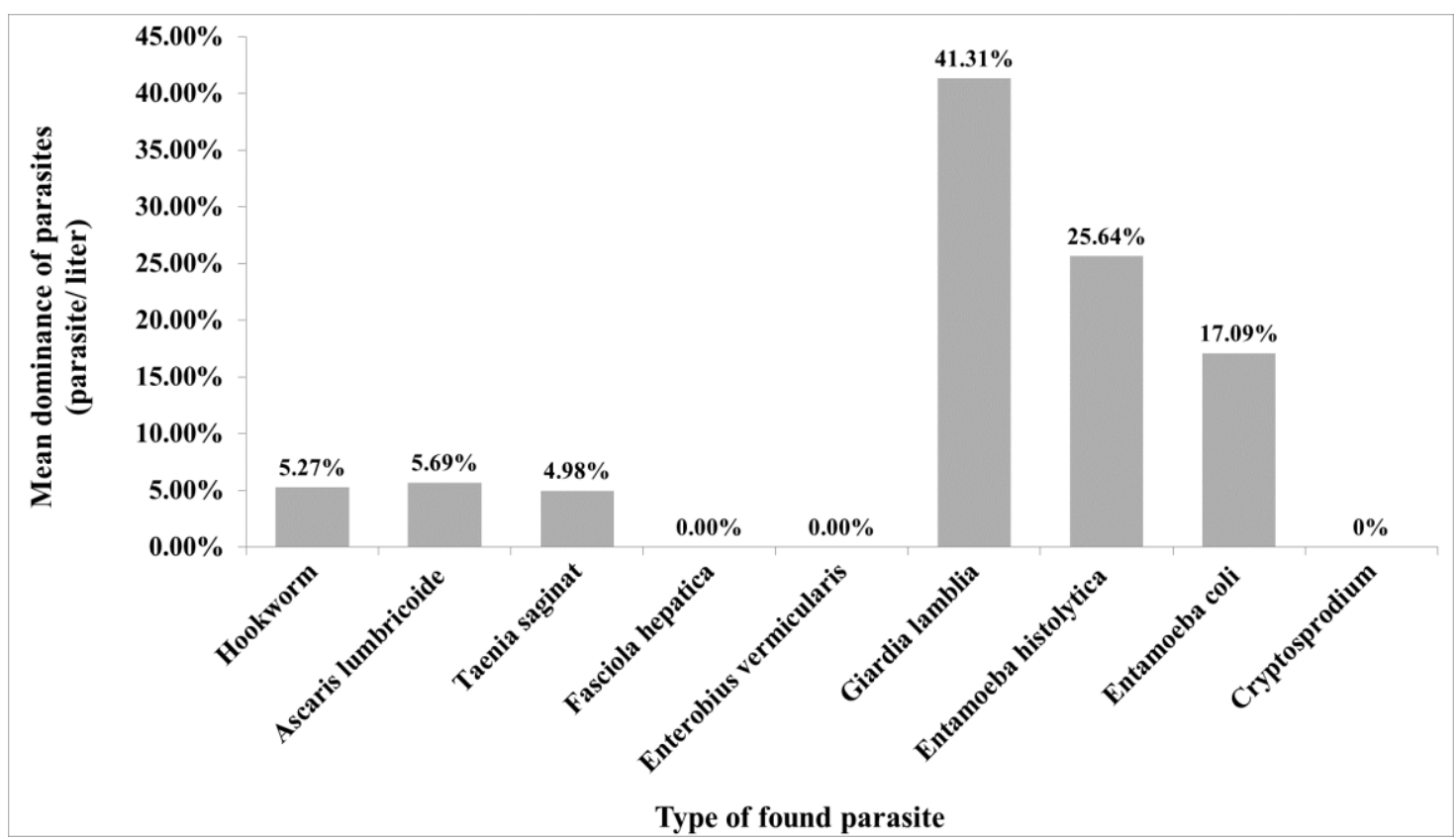

Figure 4b: Mean dominance of parasites in June sampling point.

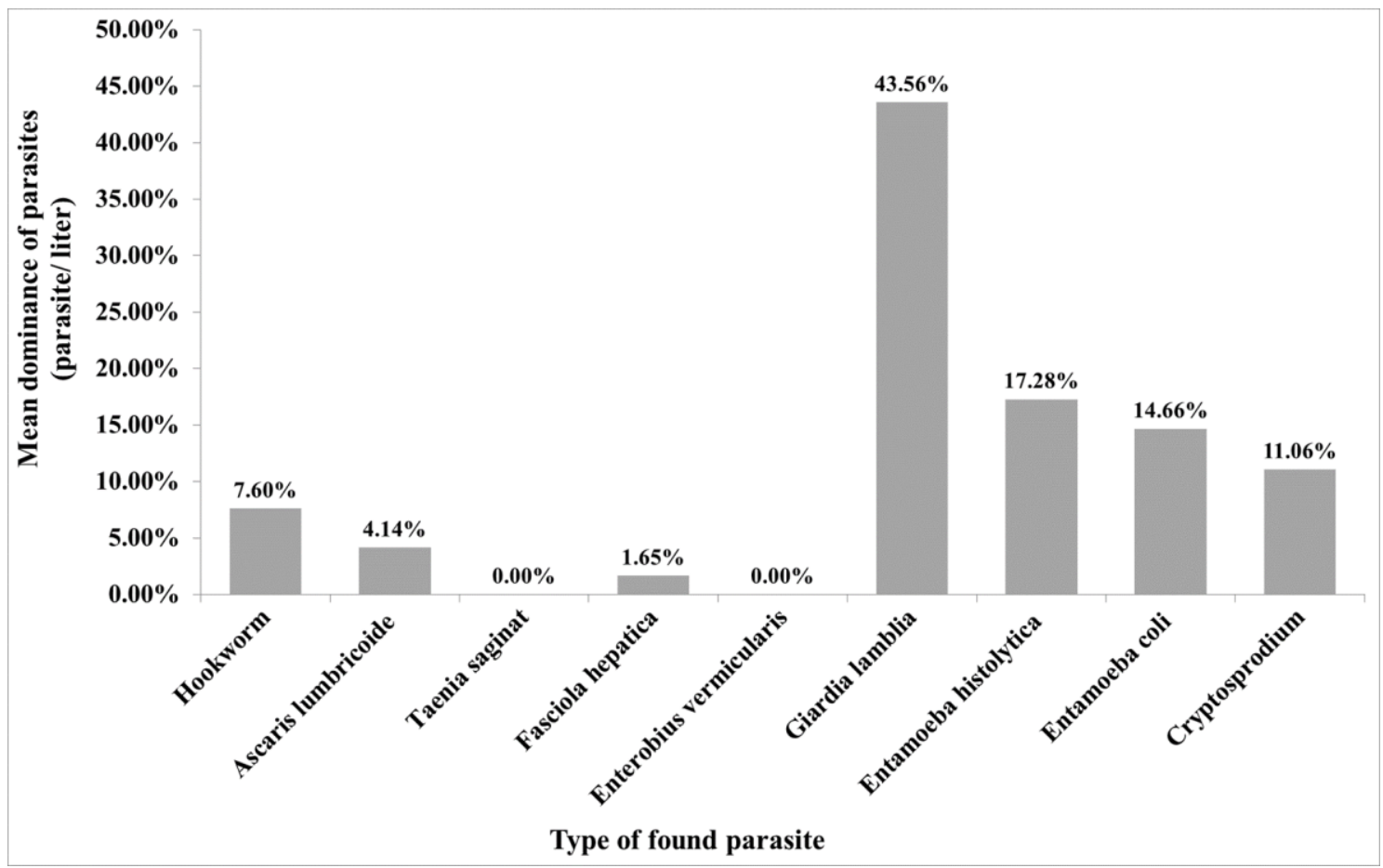

Figure 4c: Mean dominance of parasites in August sampling point.

Wastewater is a reliable source of water which is often used for irrigation purpose, especially in those areas with limited availability of fresh water. However, the treatment of wastewater is critical for the elimination of waterborne parasites including protozoa and helminths. The efficacy of treatment method that is employed in wastewater treatment plan 
should be performed repeatedly through the investigation of abundance of pathogenic parasites in the treated wastewater.

In our study, the results reveal that most of the waterborne parasites observed in wastewater treatment plant in Rada'a city are related to Giardia lamblia, Entamoeba histolytica, Entamoeba coli, Hookworms and Ascaris lumbricoide which exceed the permitted levels by WHO guidelines 2006. These kinds of parasites may get more resistance to treatment materials. The presence of amoeba and Giardia trophozoits were detected in almost all the samples diagnosed which indicates their ability to survive treatment processes (Yoder \& Beach 2010). According to WHO guidelines, treated wastewater should contain $\leq 1$ egg of helminth per litre to be suitable for use in restricted and unrestricted agriculture. In case of protozoa parasites, a reduction of 6-7 log units for unrestricted agriculture and 2-3 log units for restricted agriculture is required (WHO, 2006). A study conducted by Marin in Spain on the efficiency of wastewater treatment plant for elimination of pathogens identified the presence of Giardia and Acanthamoeba cysts in the treated sewage water, which is consistent with our study (Marín et al., 2014). On the other hand, our study is consistent with studies that detected Giardia cysts, Hookwarms eggs and Cryptosporidium oocysts in treated sewage water (Cheng et al., 2009; Tonani et al., 2011).

The concentration of parasites in treated wastewater depends mainly on efficacy of the treatment system, initial concentration of parasites in raw sewage, types of parasites and their resistance level (Kolawole \& Kan 2016; Jimenez et al ., 2017). Therefore, disappearance of some types of waterborne parasites in our study may be due to the effect of these factors. Generally, in the treated wastewater, the concentration of protozoa was significantly higher than helminth eggs. This may be due to their small size and high resistance to treatment system (Alouini, 1993). It is possible to reduce the helminth eggs up to the permissible limit of WHO (less than $1 \mathrm{egg} / \mathrm{L}$ ) (Tyagi et al., 2011), also, the removal efficiency for Giardia cysts in a study by Wiandt et al was 99\% and 99.5-99.8\% (Wiandt, 2000). To achieve this level, well-designed treatment systems should be used for removing highly resistant pathogenic organisms such as helminths and protozoa.

\section{Conclusion and Suggestion}

The present study aimed at detecting the pathogenic waterborne parasites in the treated wastewater of Rada'a city, Republic of Yemen. The results of the study indicate that the quantity of parasites in sewage after treatment exceeded the permitted levels and it is necessary to modify the treatment process of wastewater to prevent the possible spread of parasitic contamination. The proper treatment of wastewater is important to protect the public from risks acquired through prevalence of pathogenic microorganisms including protozoa and helminthes. Therefore, it is important to monitor the function and maintenance of wastewater treatment systems to ensure the removal and destruction of waterborne parasites in water effluent from wastewater treatment plants. 


\section{Conflict of Interest}

The authors of the article declare no conflict of interest.

\section{Funding}

This research study was not funded by any institution. The authors conducted the study on their own expenses.

\section{References}

Alouini, Z.(1993). Fate of parasites in five wastewater treatment plants in Tunisia. Rev. water Sci., vol. 6, pp. 453ㄴ?362.

Cheng, H. A., Graczyk, T. K., Broaders, M. A,. Tamang, L. \& Connolly, M .(2009). Fate of Cryptosporidium parvum and Cryptosporidium hominis and Giardia duodenalis cysts during secondary wastewater treatments. Parasitol Res, 10(56): 89-96.

Cheesbrough, M., (2004). District Laboratory Practice in Tropical Countries, Part I. Cambridge University Press: UK. 454 pp.

Eaton, A. D., Franson, M. A. H., Association, A.P.H., Association, A.W.W. \& Federation, W. E.(2005). Standard Methods for the Examination of Water \& Wastewater. 21, editor: American Public Health Association.

Fewtrell, L., Godfree, A., Jones, F., Kay, D., \& Merrett, H. (1994). Pathogenic microorganisms in temperate environmental waters. Samara Publishing Ltd.

Guerrant, R. L., Hughes, J. M., Lima, N. L., \& Crane, J. (1990). Diarrhea in developed and developing countries: magnitude, special settings, and etiologies. Reviews of infectious diseases, 12(Supplement_1), S41-S50.

Hatam, Nahavandi. K., Mahvi, A. H., Mohebali, M., Keshavarz, H., Mobedi, I. \& Rezaeian, M. (2015). Detection of parasitic particles in domestic and urban wastewaters and assessment of removal efficiency of treatment plants in Tehran, Iran. J Environ Health Sci Eng., 13 (1): 4-19.

Hespanhol, I. (1997). Wastewater as a resource. In: Water pollution control. A Guide to the Use of Water Quality Management Principles. F.N. Spon, London on behalf of UNESCO: WHO and UNEP.

Jimenez, B., Maya, C., Barrios, J. A. \&Navarro, I.(2017).Helminths and their Role in Environmental Engineering. In Human Helminthiasis, pp. 39?]62.

Kolawole, A. \& Kan, I.(2016). Analysis and Modeling of Wastewater Reuse Externalities in African Agriculture. J. Econ. Sustain. Dev., vol. 7, no. 9, pp. 70-80.

Lim, Y.A.L., Hafiz, W. W.I. \& Nissapatorn, V.(2007). Reduction. of Cryptosporidium and Giardia by sewage treatment processes. Tropical Biomedicine, 24(1): 950104.

Marín,I. G.G.P.M.I., Lasheras, M. A., Lasheras, M. A. \& Ormad, M. P. (2014). Efficiency of a Spanish wastewater treatment plant for removal potentially pathogens: Characterization of bacteria and protozoa along water and sludge treatment lines. Ecol Eng, 74 (5): 28-32. 
Miranzadeh, M.B. \& Mahmodi, S.(2002). Investigation into the Removal of Nematodes Eggs in Influent and Effluent of Shoosh Wastewater Treatment Plant. water and wastewater. Persian, 42 (32): 6-17.

Miegeville, M., Koubi, V., Dan, L.C., Barbier, J.P. \& Cam, P.D.(2003). Cyclospora cayetaensis presence in milieu hydrique al Hanoi (Vietnam). Etude dans 1' environment (eaux de forage, lacs et rivie??res). Bull. Soc. Pathol. Exot., 96: 149-152.

Zurita, F. \& White, J. R. (2014).Comparative study of three two-stage hybrid ecological wastewater treatment systems for producing high nutrient, reclaimed water for irrigation reuse in developing countries. Water, vol. 6, pp. 213-228.

Okoh, A. I. ,Odjadjare, E. E., Igbinosa, E. O. \& Osode, A. N. (2007).Wastewater treatment plants as a source of microbial pathogens in receiving watersheds. African $J$. Biotechnol, vol. 6, no. 25, pp. 2932-2944.

Ortolani, E.L. (2000).Standardization of the modified ziehl- neelsen technique to stain oocysts of Cryptosporidium sp. Brazilian Journal of Veterinary Parasitology, 9(1):2931.

Patricia, M. I. B., Gemma, A.\& Estanislao, D.L. (2008). Removal of wastewater pathogen indicators in a constructed wetland in Leon. Spain. Ecol Eng., 33 (3): 25-27.

Steiner, T.S., Thielman, N.M. \& Guerrant, R.L.(1997). Protozoal agents: what are the dangers for the public water supplies? Annu. Rev. Med., 48: 329-340.

Tonani, K.A.A., Trevilato, T.M.B., Takayanagui, A.M.M., Bocio, A., Domingo, J.L. \& Segura-Muñoz, S.I. (2011). Behavior of metals, pathogen parasites, and indicator bacteria in sewage effluents during biological treatment by activated sludge. Biol Trace Elem Res, 14 (31):193-201.

Tyagi, V.K., Sahoo, B., Khursheed, A., Kazmi, A., Ahmad,Z. \& Chopra, A .(2011). Fate of coliforms and pathogenic parasite in four full-scale sewage treatment systems in India. Environ Monit Assess, 181 (1):123-35.

Wiandt, S.G.A.M., Balux, B. \& Bontoux, J .(2000). Efficiency. of wastewater treatment plants at removing Giardia sp. Cysts in southen France-Schriftenr Ver Wasser. Boden Lufthyge. 10 (5): 35-42.

World Health Organization.(2006). Guideline for the safe use of wastewater excreta and greywater. I. Geneva.

Yoder, J. \& Beach, M. (2010). Cryptosporidium surveillance and risk factors in the United States. Exp. Parasitol, 124, 31-39. 